\title{
Evaluation of cases of kerosene poisoning: A 3-year prospective study at Menoufia University Hospitals
}

\author{
Shireen Ragab Slima ${ }^{1}$, Eman Ragab ${ }^{2}$, and Shaimaa Abdalaleem Abdalgeleel ${ }^{3}$ \\ ${ }^{1}$ Forensic Medicine and Clinical Toxicology Department, Faculty of Medicine, Menoufia University, Egypt. \\ ${ }^{2}$ Radiodiagnosis Department, Faculty of Medicine, Menoufia University, Egypt. \\ ${ }^{3}$ Department of biostatistics and epidemiology, National cancer institute, Cairo University, Egypt.
}

\begin{abstract}
Background: kerosene is a common cause of childhood poisoning specially in low and middleincome countries. Complications are primarily related to pulmonary aspiration which is a significant contributor to Intensive Care Unit (ICU) admission.

Objectives: To study the clinical profile of kerosene poisoning in children presented to Menoufia Poison Control Centre and to identify patients who need ICU admission.

Methods: a prospective study including children presented to Menoufia Poison Control Center with acute kerosene poisoning during the period of three years from 2018 to 2020.

Results: During the study period, a total number of 154 children were admitted. Male children were $56.5 \%$ and females represent $43.5 \%$. More than half of cases $(52.6 \%)$ were less than 3 years. The majority of cases were from rural areas $(76.6 \%)$. All cases were exposed to kerosene orally and $24.9 \%$ had combined oral and dermal exposure. ICU admitted cases had longer period of hospitalization and presented mainly by tachypnea, hypoxemia and chest retractions.

Conclusion: Respiratory system is mainly affected in kerosene poisoning. Patients presenting with respiratory distress, moderate or severe grades of PSS, hypoxemia on presentation should be admitted to the ICU. Community education is necessary to reduce this preventable poisoning in children.

Key words Hydrocarbons, Kerosene poisoning, Pneumonitis
\end{abstract}

\section{Introduction}

$\mathrm{P}$ oisoning is a common and preventable cause of morbidity and mortality in pediatric age group as the surrounding environment is still not child safe (Murmu and Das, 2017). Kerosene ingestion is a common medical emergency among children in developing countries where it is still used for cooking, heating, and lighting coupled with suboptimal care and supervision of children (Anwar et al., 2014). Kerosene, also known as paraffin, is obtained from the fractional distillation of petroleum. It is a cheap fuel hydrocarbon nearly colorless and most times, is stored in familiar containers at homes (Singh and Gurung, 2018).

Pulmonary complications are commonly reported in kerosene ingestion. Aspiration frequently occurs, either initially or when the patient coughs or vomits. Low viscosity promotes penetration into more distal airways and lower surface tension increases spread over a larger area of lung tissue (Sunilkumar and Parvathy, 2016). Chemical pneumonitis usually results from direct injury to the lung parenchyma. Type II pneumocytes are the most affected resulting in decreased surfactant production that leads to alveolar collapse and hypoxemia (Prasad et al., 2011).

Gastrointestinal involvement is manifested by vomiting, abdominal pain and diarrhea is attributed to mucosal irritation (Shotar, 2005). Systemic effects include cardiac arrhythmia and central nervous system
(CNS) depression (Tawfik and Hafiz, 2017). Standard treatment for acute accidental hydrocarbon poisoning includes resuscitation, removal of all contaminated clothing, decontamination of exposed skin with soap and water. Assessment of respiration, maintenance of oxygenation and correction of fluid and electrolyte imbalance should be done as indicated (Das et al., 2020).

Due to limited resources especially in developing countries, it may not be possible to admit all patients with acute poisoning to an intensive care unit. Based on clinical parameters recorded on admission, prediction of the need for ICU admission enables clinicians to identify patients at higher risk allowing more intensive monitoring and treatment.

\section{Patients and Methods}

This work was conducted as a prospective study including all children less than 18 years with kerosene poisoning presented to Menoufia Poisoning Control Center (MPCC) during the period from 2018 to 2020.

The diagnosis of poisoning was based on history of exposure taken from the patient and/or the patient's parent. Clinical observation included kerosene odor, assessment of the level of consciousness, vitals, and signs of respiratory distress. Normal values of clinical data were considered according to Nelson et al., (2011). 
All patients were subjected to full history taking, general examination, complete blood count (CBC) and arterial blood gases (ABG). Plain chest Xray was done after 6 hours of consumption and repeated according to clinical indication. All chest radiographs were re-checked by trained radiologist.

The studied cases were classified according to Poison Severity Score (PSS) on admission. The PSS classifies poisoning severity as none (Grade-0), minor (Grade-1), moderate (Grade-2), severe (Grade-3), and fatal (Grade-4) (Persson et al., 1998).

All cases were admitted and managed according to the protocol of management of MPCC. Skin decontamination was applied for patients with dermal exposure. Gastric lavage was not done. Administration of supplemental oxygen and inhaled bronchodilators were used for wheezing. Antibiotics were administered when a secondary bacterial infection is suspected. Oxygenation and fluid and electrolyte balance were maintained.

Cases were classified into two groups; ICU admitted cases and non-ICU admitted cases. Acutely poisoned patients manifested with profound change in any vitals, hemodynamic instability, altered mental status or severe electrolyte disturbance likely require ICU admission (Kirk, 2011).

\section{Exclusion criteria:}

Cases with co-ingestion, having associated diseases affecting the respiratory, cardiovascular or central nervous system and cases more than 18 years old were excluded.

\section{Statistical analysis}

The Statistical Package of Social Science (SPSS, version 26) was used to generate results. Data were described using number and percent. Relation between qualitative data was done using Chi-square test or Fisher's exact test as appropriate. P-value less than 0.05 was considered statistically significant.

\section{Ethical consideration:}

The study was approved by the Menoufia Research Ethical Committee (Approval code: 5/2020RAD4) as well as the authority of the Menoufia Poisoning Control Center. Confidentiality of patients' information was maintained. Informed consent was taken from their guardians after explanation of the aim of the work.

\section{Results}

This study was performed on 154 cases with kerosene poisoning, out of them 18 were admitted to ICU representing $11.7 \%$ with a mortality rate of $1.9 \%$ ( 3 cases died). All the cases were exposed to kerosene accidentally. The demographics and toxicological information for cases in the ordinary ward and ICU are summarized in table (1). The results illustrated that more than half of the cases were less than 3 years. The younger age group was more associated with ICU admission.

The majority of cases were males $(56.5 \%)$ and from rural areas $(76.6 \%)$. Regarding sex and residence, the relation was not statistically significant between the two groups.

All cases were exposed to kerosene orally and $24.9 \%$ had combined oral and dermal exposure. Route of poisoning significantly affected ICU admission, the children poisoned by dermal and oral route needed ICU admission more than children poisoned by oral root only (p-value $<0.001$ ).

Table (1) reveals that $93.5 \%$ of all children ingested less than $10 \mathrm{ml}$. Children who received $\geq 10$ $\mathrm{ml}$ significantly needed ICU admission more than those who received less than $10 \mathrm{ml}$ (70\% compared to $7.6 \%$, p-value $<0.001$ ).

The result illustrated that $97 \%$ of children who did not receive pre-hospital treatment were admitted in the ordinary ward, while $27.3 \%$ of cases with induced vomiting or given milk were admitted in ICU. Most of the cases (64.3\% of all cases) were referred with a nonsignificant difference between the two groups ( $\mathrm{p}$-value $=0.073$ ).

Presentations within the first 2 hours of exposure were recorded in $63 \%$ of cases. Children with a delay time to presentation more than 2 hours significantly needed ICU admission more than those presented within 2 hours $(24.6 \%$ vs $4.1 \%$, p-value $<0.001$ ) (Table 1).

The period of hospitalization was less than one week in cases admitted in the ordinary ward, while cases admitted to ICU stayed more than a week with a significant difference $(p<0.001)$ between the two groups.

According to Poison Severity Score, 65.5\% of all cases $(=101)$ were among Grade-0 (asymptomatic) and Grade-1 (minor) and were admitted in ordinary ward. Cases with moderate (Grade-2) and severe PSS needed more ICU admission compared to cases with none or mild PSS with a statistically significant value (p-value $<0.001$ ).

According to vital signs, $51.3 \%$ of all cases presented with hyperthermia, $21.4 \%$ with tachycardia and tachypnea, and $14.9 \%$ with hypotension. Cases presented with tachycardia needed ICU admission more than children presented by normal pulse, $(34.4 \%$ VS $5.0 \%$, p-value $<0.001$ ). A high proportion of children presented with tachypnea needed ICU admission more than children with a normal respiratory rate (54.5 VS $0, \mathrm{p}$-value $<0.001)$. It was also found that $39.4 \%$ of children presented with hypotension and $20.3 \%$ of children who presented with hyperthermia needed ICU admission (p-value <0.001, 0.001 respectively) (Table 2).

Considering clinical presentation, patients predominantly presented with respiratory symptoms. Cough was the commonest clinical finding in kerosene poisoning (46.1\% of all cases). Other manifestations included chest retraction (10.4\%), wheezy chest $(33.8 \%)$, diminished air entry $(10.4 \%)$, and hypoxia (9.7\%). Vomiting occurred in $23.4 \%$ of all cases. Drowsiness was observed in $8.4 \%$ of cases; most of them were admitted to ICU. Blood manifestations in the form of anemia and leukocytosis were recorded in $8.4 \%$ and $14.9 \%$ of all patients respectively. These clinical parameters were statistically correlated to incidence of ICU admission (Table 3).

As regard radiological results, sixty-eight patients $(55.8 \%)$ had radiological findings of lung 
pathology, whereas $86(44.2 \%)$ of them were radiologically free. Peribronchial cuffing was the commonest $(52.3 \%)$ (Figure 1), followed by subtle opacity (18.6\%). Radiological evidence of pneumonia (consolidation) was found mainly in the right lung (16.3\% of all cases) (Figure 2). Most cases with lung consolidation required ICU admission as shown in (Table 4).

Approximately three-quarters of patients were cured $(117=76.0 \%)$ and discharged without any complications, however 34 patients $(22.1 \%)$ discharged against medical advice. Only 3 deaths were recorded, all deaths occurred among ICU cases (Table 5).

Table 1: Chi Square Statistical Analysis of demographics and toxicological information for studied cases with kerosene poisoning

\begin{tabular}{|c|c|c|c|c|c|c|c|}
\hline & \multicolumn{4}{|c|}{ ICU admission } & \multirow{3}{*}{$\begin{array}{c}\text { Total } \\
(n=154)\end{array}$} & \multirow{3}{*}{$P$-value } \\
\hline & & \multicolumn{2}{|c|}{$\begin{array}{c}\text { Yes } \\
(n=18)\end{array}$} & \multicolumn{2}{|c|}{$\begin{array}{c}\text { No } \\
(n=136)\end{array}$} & & \\
\hline & & $\mathbf{N}$ & $\%$ & $\mathbf{N}$ & $\%$ & & \\
\hline \multirow{2}{*}{ Age (years) } & $<3$ & 13 & 16.0 & 68 & 84.0 & $81(52.6)$ & \multirow{2}{*}{0.076} \\
\hline & $\geq 3$ & 5 & 6.8 & 68 & 93.2 & $73(47.4)$ & \\
\hline \multirow{2}{*}{ Gender } & Male & 11 & 12.6 & 76 & 87.4 & $87(56.5)$ & \multirow{2}{*}{0.674} \\
\hline & Female & 7 & 10.4 & 60 & 89.6 & $67(43.5)$ & \\
\hline \multirow{2}{*}{ Residence } & Urban & 4 & 11.1 & 32 & 88.9 & $36(23.4)$ & \multirow{2}{*}{0.902} \\
\hline & Rural & 14 & 11.9 & 104 & 88.1 & $118(76.6)$ & \\
\hline \multirow{2}{*}{$\begin{array}{l}\text { Route of } \\
\text { poisoning }\end{array}$} & Oral & 10 & 7.6 & 121 & 92.4 & $131(85.1)$ & \multirow{2}{*}{$<0.001 *$} \\
\hline & Dermal \& oral & 8 & 34.8 & 15 & 65.2 & $23(24.9)$ & \\
\hline \multirow{2}{*}{ Quantity (ml) } & $<10 \mathrm{ml}$ & 11 & 7.6 & 133 & 92.4 & $144(93.5)$ & \multirow{2}{*}{$<0.001^{*}$} \\
\hline & $\geq 10 \mathrm{ml}$ & 7 & 70.0 & 3 & 30.0 & $10(6.5)$ & \\
\hline \multirow{2}{*}{$\begin{array}{l}\text { Pre-hospital } \\
\text { treatment }\end{array}$} & None & 3 & 3.0 & 96 & 97.0 & $99(63.3)$ & \multirow[b]{2}{*}{$<0.001 *$} \\
\hline & $\begin{array}{c}\text { Induced } \\
\text { vomiting/milk }\end{array}$ & 15 & 27.3 & 40 & 72.7 & $55(35.7)$ & \\
\hline \multirow{2}{*}{ Referral } & Yes & 15 & 15.2 & 84 & 84.8 & $99(64.3)$ & \multirow{2}{*}{0.073} \\
\hline & No & 3 & 5.5 & 52 & 94.5 & $55(35.7)$ & \\
\hline \multirow{2}{*}{$\begin{array}{l}\text { Delay time till } \\
\text { presentation }\end{array}$} & $\leq 2$ hours & 4 & 4.1 & 93 & 95.9 & $97(63.0)$ & \multirow{2}{*}{$<0.001 *$} \\
\hline & $>2$ hours & 14 & 24.6 & 43 & 75.4 & $57(37.0)$ & \\
\hline \multirow{3}{*}{ Period of stay } & $<24 h$ & 0 & 0 & 43 & 100.0 & $43(27.9)$ & \multirow{3}{*}{$<0.001 *$} \\
\hline & 24h- week & 5 & 5.1 & 93 & 94.9 & $98(63.6)$ & \\
\hline & > week & 13 & 100 & 0 & 0 & $13(8.4)$ & \\
\hline \multirow{2}{*}{ PSS on admission } & None-minor & 0 & 0 & 101 & 100 & $101(65.7)$ & \multirow{2}{*}{$<0.001 *$} \\
\hline & Moderate-severe & 18 & 34.0 & 35 & 66.0 & $53(34.4)$ & \\
\hline
\end{tabular}

$N=$ number, ICU: intensive care unit, PSS: Poison Severity Score, $* P<0.05$ is significant.

Table 2: Chi Square Statistical Analysis of vital signs of studied cases with kerosene poisoning

\begin{tabular}{|c|c|c|c|c|c|c|c|}
\hline & & \multicolumn{4}{|c|}{ ICU admission } & \multirow{3}{*}{$\begin{array}{c}\text { Total } \\
(n=154)\end{array}$} & \multirow{3}{*}{$P$-value } \\
\hline & & \multicolumn{2}{|c|}{$\begin{array}{c}\text { Yes } \\
(n=18)\end{array}$} & \multicolumn{2}{|c|}{$\begin{array}{c}\text { No } \\
(n=136)\end{array}$} & & \\
\hline & & $\mathbf{N}$ & $\%$ & $\mathbf{N}$ & $\%$ & & \\
\hline \multirow{2}{*}{ Pulse } & Normal & 6 & 5.0 & 115 & 95.0 & $121(78.6)$ & \multirow{2}{*}{$<0.001 *$} \\
\hline & Tachycardia & 12 & 34.4 & 21 & 63.6 & $33(21.4)$ & \\
\hline \multirow{2}{*}{ Blood pressure } & Normal & 9 & 6.9 & 122 & 93.1 & $131(85.1)$ & \multirow{2}{*}{$<0.001 *$} \\
\hline & Hypotension & 9 & 39.1 & 14 & 60.9 & $23(14.9)$ & \\
\hline \multirow{2}{*}{ Temperature } & Normal & 2 & 2.7 & 73 & 97.3 & $75(48.7)$ & \multirow{2}{*}{$0.001 *$} \\
\hline & Hyperthermia & 16 & 20.3 & 63 & 79.7 & $79(51.3)$ & \\
\hline \multirow{2}{*}{ Respiratory rate } & Normal & 0 & 0 & 121 & 100 & $121(78.6)$ & \multirow{2}{*}{$<0.001 *$} \\
\hline & Tachypnea & 18 & 54.5 & 15 & 45.5 & $33(21.4)$ & \\
\hline
\end{tabular}

$N=$ number, Hyperthermia $>37.5^{\circ} \mathrm{C}$, Tachypnea $>30 / \mathrm{min}, * P<0.05$ is significant 
Table 3: Chi Square Statistical Analysis of the clinical presentations and laboratory findings of the studied cases with kerosene poisoning

\begin{tabular}{|c|c|c|c|c|c|c|c|}
\hline & \multicolumn{4}{|c|}{ ICU admission } & \multirow{3}{*}{$\begin{array}{c}\text { Total } \\
(n=154)\end{array}$} & \multirow{3}{*}{$P$-value } \\
\hline & & \multicolumn{2}{|c|}{ Yes $(n=18)$} & \multicolumn{2}{|c|}{ No $(n=136)$} & & \\
\hline & & $\mathbf{N}$ & $\%$ & $\mathbf{N}$ & $\%$ & & \\
\hline \multirow{2}{*}{ Cough } & Absent & 5 & 6.0 & 78 & 94.0 & $83(53.9)$ & \multirow{2}{*}{$0.018 *$} \\
\hline & Present & 13 & 18.3 & 58 & 81.7 & $71(46.1)$ & \\
\hline \multirow{2}{*}{$\begin{array}{c}\text { Chest retractions } \\
\text { and use of accessory } \\
\text { muscles }\end{array}$} & Absent & 2 & 1.4 & 136 & 98.6 & $138(89.6)$ & \multirow[b]{2}{*}{$<0.001 *$} \\
\hline & Present & 16 & 100 & 0 & 0 & $16(10.4)$ & \\
\hline \multirow{3}{*}{ Chest auscultation } & Free & 0 & 0 & 86 & 100 & $86(55.8)$ & \multirow{3}{*}{$<0.001 *$} \\
\hline & Wheezes & 4 & 7.7 & 48 & 92.3 & $52(33.8)$ & \\
\hline & $\begin{array}{c}\text { Diminished air entry } \\
\pm \text { Crepitations }\end{array}$ & 14 & 87.5 & 2 & 12.5 & $16(10.4)$ & \\
\hline \multirow{2}{*}{ Hypoxia } & Absent & 3 & 2.2 & 136 & 97.8 & $139(90.3)$ & \multirow{2}{*}{$<0.001 *$} \\
\hline & Present & 15 & 100 & 0 & 0 & $15(9.7)$ & \\
\hline \multirow{2}{*}{$\begin{array}{c}\text { Vomiting } \\
\text { (spontaneous or } \\
\text { induced) }\end{array}$} & Absent & 3 & 2.5 & 115 & 97.5 & $118(76.6)$ & \multirow{2}{*}{$<0.001 *$} \\
\hline & Present & 15 & 41.7 & 21 & 58.3 & $36(23.4)$ & \\
\hline \multirow{2}{*}{ Drowsiness } & Absent & 8 & 5.7 & 133 & 94.3 & $141(91.6)$ & \multirow{2}{*}{$<0.001 *$} \\
\hline & Present & 10 & 76.9 & 3 & 23.1 & $13(8.4)$ & \\
\hline \multirow{2}{*}{ Anemia } & Absent & 14 & 9.9 & 127 & 90.1 & $141(91.6)$ & \multirow{2}{*}{$0.025^{*}$} \\
\hline & Present & 4 & 30.8 & 9 & 69.2 & $13(8.4)$ & \\
\hline \multirow{2}{*}{ Leukocytosis } & Absent & 11 & 8.4 & 120 & 91.6 & $131(85.1)$ & \multirow{2}{*}{$0.002 *$} \\
\hline & Present & 7 & 30.4 & 16 & 69.6 & $23(14.9)$ & \\
\hline
\end{tabular}

$\mathrm{N}=$ number, Hypoxia $\mathrm{PaO}_{2}<60 \mathrm{mmHg}$ in room air, Leukocytosis WBC counts $>15000 / \mathrm{mm}^{3}$, Normal Hb >11 gm/dl according to the age group, * $P<0.05$ is significant

Table 4: Chi Square Statistical Analysis of the radiological findings in the studied cases of kerosene poisoning

\begin{tabular}{|c|c|c|c|c|c|c|}
\hline & \multicolumn{4}{|c|}{ ICU admission } & \multirow{3}{*}{$\begin{array}{c}\text { Total } \\
(n=154)\end{array}$} & \multirow{3}{*}{$P$ - value } \\
\hline & \multicolumn{2}{|c|}{$\begin{array}{c}\text { Yes } \\
(n=18)\end{array}$} & \multicolumn{2}{|c|}{$\begin{array}{c}\text { No } \\
(n=136)\end{array}$} & & \\
\hline & $\mathbf{N}$ & $\%$ & $\mathbf{N}$ & $\%$ & & \\
\hline Normal & 0 & 0 & 68 & 100 & $68(44.2)$ & \multirow[b]{2}{*}{$<0.001 *$} \\
\hline $\begin{array}{c}\text { The radiological finding of lung } \\
\text { pathology }\end{array}$ & 18 & 20.9 & 68 & 79.1 & $86(55.8)$ & \\
\hline \multicolumn{7}{|l|}{ Pattern of abnormalities $(n=86)$} \\
\hline Peribronchial cuffing & 0 & 0 & 45 & 100 & $45(52.3)$ & \\
\hline Subtle opacity & 0 & 0 & 16 & 100 & $16(18.6)$ & \\
\hline Unilateral right consolidation & 8 & 57.1 & 6 & 42.9 & $14(16.3)$ & \\
\hline Unilateral left consolidation & 3 & 75.0 & 1 & 25 & $4(4.7)$ & \\
\hline Bilateral consolidation & 7 & 100 & 0 & 0 & $7(8.1)$ & \\
\hline
\end{tabular}

Consolidation may occupy a portion or whole of a lobe or the entire lung, $* P<0.05$ is significant.

Table 5: Outcome of the studied cases with kerosene poisoning

\begin{tabular}{|c|c|c|c|c|c|c|}
\hline & & \multicolumn{4}{|c|}{ ICU admission } & \multirow{3}{*}{$\begin{array}{c}\text { Total } \\
(n=154)\end{array}$} \\
\hline & & \multicolumn{2}{|c|}{$\begin{array}{c}\text { Yes } \\
(n=18)\end{array}$} & \multicolumn{2}{|c|}{$\begin{array}{c}\text { No } \\
(n=136) \\
\end{array}$} & \\
\hline & & $\mathbf{N}$ & $\%$ & $\mathbf{N}$ & $\%$ & \\
\hline \multirow{3}{*}{ Outcome } & Cured & 15 & 12.8 & 102 & 87.2 & $117(76.0)$ \\
\hline & DAMA & 0 & 0 & 34 & 100 & $34(22.1)$ \\
\hline & Death & 3 & 100 & 0 & 0 & $3(1.9)$ \\
\hline
\end{tabular}




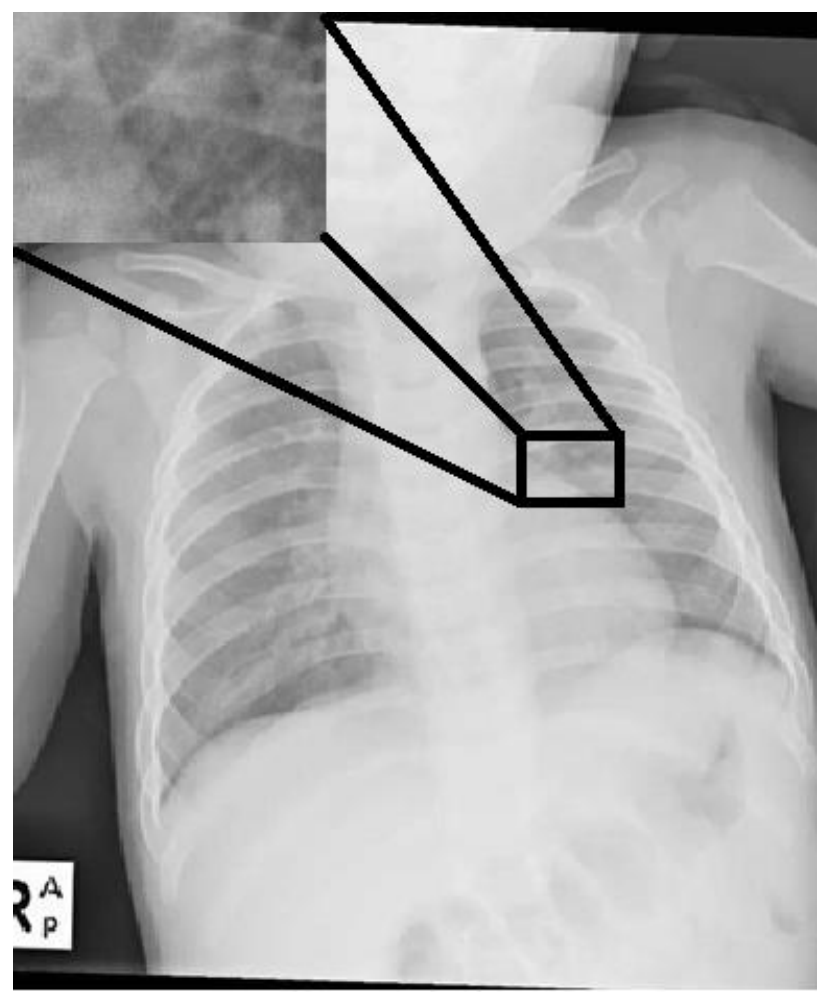

Figure 1: Chest x-ray of three-year old male patient with peribronchial cuffing.

\section{Discussion}

This was a prospective study in which a total of 154 patients with kerosene poisoning were included with ICU admission to 18 of them (11.7\%). Venkatesh et al., (2011) recorded that $10 \%$ of cases admitted with kerosene poisoning in India required pediatric intensive care. In the same line, Madboly and Elgendy (2014) found that $12.5 \%$ of hydrocarbon patients were admitted to ICU.

In the present study, more than half of cases were in the age group ( $<3$ years). This age is highly vulnerable because of their adventurous behavior and curiosity to explore the surrounding environment (Sunilkumar and Parvathy, 2016).

Younger age is associated with more ICU admission due to higher risk of respiratory system affection due to sensitive respiratory center, high possibility of aspiration during vomiting and narrow airway (Joshi and Ross, 2017). This was in accordance with Lifshitz et al., (2003) who reported that children treated in the intensive care unit (ICU) aged 1 to 3 years. Additionally, Tawfik and Hafiz (2017) recorded that the highest percent of hydrocarbon deaths were in the age group (>2 - $\leq 3$ years).

In the present study, males outnumbered females. Male dominance could be due to more aggressive and exploratory nature and their greater degree of activity (Qazi and Saqib, 2018). Other studies showed similar age and gender predominance were reported by Al-Naddawi et al., (2009) in Iraq, Anwar et al., (2014) in Bangladesh, Kumaravel and

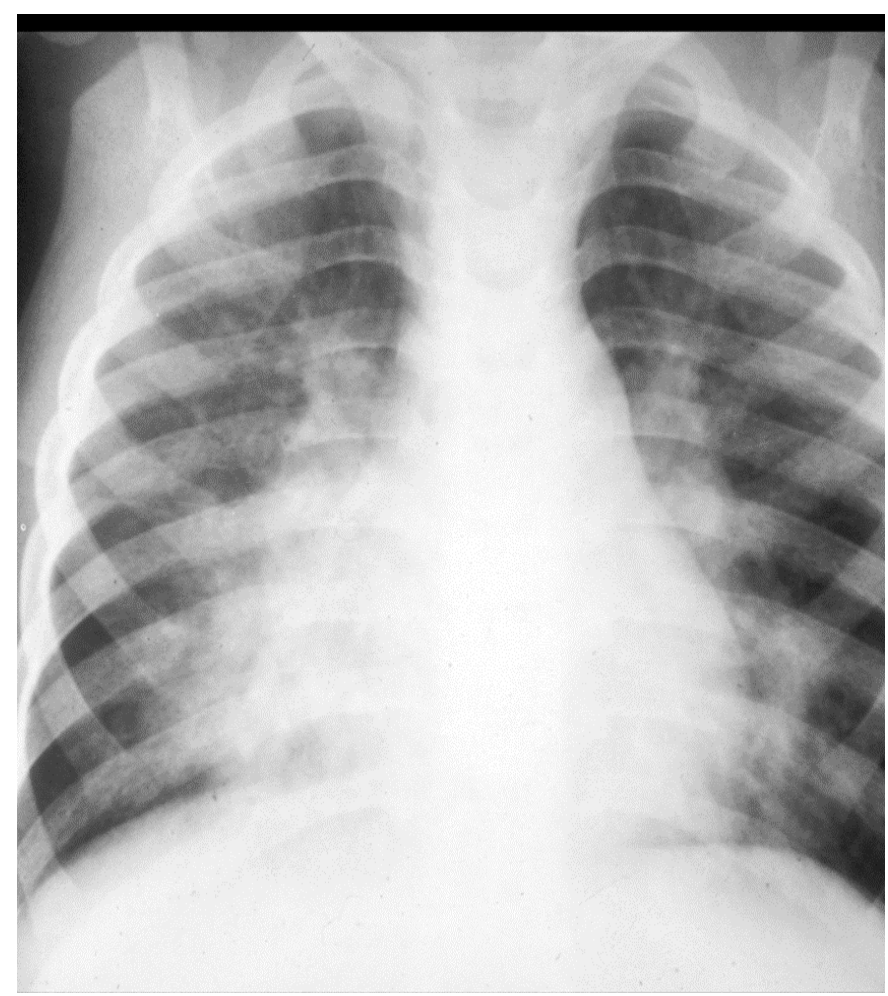

Figure 2: Chest X-ray of five-year old male patient with bilateral consolidations mainly lower zonal (right> left)

Rameshbabu (2016) in India, and by Singh and Gurung, (2018) in Pakistan.

As regards mode of poisoning, all cases were poisoned accidentally because of easy availability of kerosene at their homes. This was previously reported by Lang et al., (2008). The present study did not record any intentional ingestions of kerosene in contrast with previous Egyptian studies made by Madboly and Elgendy, (2014) and Tawfik and Hafiz (2017).

The current study showed that most of poisoned children were from rural areas due to more availability of kerosene and less supervision of parents to their children. This was previously reported by Sunilkumar and Parvathy (2016). This was different from the finding of Manzar et al., (2010) who observed more exposure from urban areas due to child neglect caused by maternal employment.

All cases were exposed to kerosene orally, as a young child is used to explore object by putting it in his mouth. Concomitant dermal exposure occurred in $34.8 \%$ of ICU cases mostly due to vomiting which increase the risk of aspiration pneumonia.

It is usually difficult to be sure about the quantity ingested because the amount stored is usually unknown and some is usually spilled. It was estimated that most children drank less than $10 \mathrm{ml}$. This agreed with the findings recorded by Siddiqui et al., (2008). Moreover, Basu (2016) mentioned that toddlers were poisoned by only a few sips of kerosene. This can be due to the disagreeable taste and odor of kerosene, so 
most children do not consume a large volume and spit it rapidly after tasting it (Madboly and Elgendy, 2014).

The current study confirmed that $63.3 \%$ of cases did not receive any pre-hospital measures. Vomiting was induced inappropriately by parents, which reflects low parental education. Induced vomiting increased the risk of ICU admission significantly. Madboly and Elgendy (2014) demonstrated increased severity of poisoning with home treatment in the form of induction of vomiting.

Regarding referral data, $64.3 \%$ of all cases were referred from other health centers. This may be due to the fact that Menoufia poisoning control center is the only center specialized in the treatment of poisoning cases in Menoufia Governorate.

This study revealed that most of the studied cases $(63 \%)$ reached the hospital within two hours after ingestion. Short delay reflects that realization of risks associated with kerosene poisoning by parents who rush their child to the hospital especially if associated with respiratory manifestations. This was previously confirmed by Siddiqui et al., (2008), while most of the delayed cases who came from remote areas were admitted to ICU. Similarly, Jayashree and Singhi (2011) recorded in their study in India a longer time interval to presentation in ICU admitted children poisoned. This fact reveals the value of community awareness of early medical intervention in improving clinical outcome of kerosene poisoning.

Short hospital stay was recorded in most studied cases which was previously reported by Lang et al., (2008). On the other hand, those with severe toxicity who were admitted to ICU and mechanically ventilated required a longer period of hospitalization. This finding was in accordance with Jayashree et al., (2006).

Scoring systems are based on simple clinical parameters which are recorded at admission. They enable clinicians to identify patients at higher risk allowing more intensive monitoring and treatment. Early identification of severity followed by prompt treatment can prevent late complications and reduce fatalities (Chandrasekhar et al., 2017).

Poisoning severity score (PSS) represents each system involved in a sequential progression. In the respiratory system, the main system targeted in kerosene poisoning, it starts with no symptoms progressing to cough followed by dyspnea and hypoxemia ending with respiratory insufficiency. In the current study, $65.5 \%$ of cases were asymptomatic (Grade-0) and minor (Grade-1) according to the PSS. Kulkarni et al., (2019) observed that $60 \%$ of children poisoned with kerosene were asymptomatic at presentation.

Abd El Salam et al., (2011) stated that the PSS was useful to predict outcome in hydrocarbon toxicity. They found that all patients with grade 0 and grade 1 recovered completely and none was admitted to the ICU, while all patients with grade 2 (Moderate) were admitted to the ICU and recovered completely. All of grade 3 (Severe) were admitted to the ICU and $75 \%$ of them died.
The current study demonstrated that $51.3 \%$ of all involved children presented with hyperthermia, $21.4 \%$ of them presented with tachycardia and tachypnea, and $14.9 \%$ presented with hypotension. Venkatesh et al., (2011) recorded tachypnea in $100 \%$ of children with kerosene aspiration, fever in $20 \%$, and tachycardia in $15 \%$ of them. Tachypnea was noted in all ICU cases. Sen et al. (2013) mentioned that tachypnea was the best clinical sign of pneumonia in children less than three years old.

The most common reported symptom was cough. This was also reported by Sheikh et al., (2013) and Anwar et al., (2014), while the study of Basu (2016) demonstrated that the most common symptom was vomiting.

Signs of respiratory distress were observed in ICU admitted children. This agreed with the study of Jayashree and Singhi (2011) who recorded that respiratory distress was a common clinical feature of acute poisoning in the pediatric ICU.

Bond et al., (2008) suggested that the presence of wheezing, altered consciousness, or tachypnea within 2 hours of hydrocarbon exposure required a higher level of care. Additionally, Sen et al. (2013) observed that patients with abnormal breath sounds at admission had longer hospital stays, hence require intense monitoring from the start.

Hypoxemia was evident in ICU admitted cases. This was previously reported by Jayashree et al., (2006). Vomiting occurred due to the irritating effect of kerosene on the gastric mucosa. Vomiting, whether spontaneous or induced, increases the risk of aspiration and the severity of pneumonia (Ahmadu et al., 2016). Drowsiness was observed mainly in ICU admitted patients due to hypoxia as it is usually associated with pulmonary manifestations.

Anemia was observed in $8.4 \%$ of kerosene poisoned patients it may be due to hemolysis associated with hydrocarbon ingestion (Biswas, 2012). Leukocytosis occurred in $14.9 \%$ of included cases as most cases of aspiration pneumonitis have no bacteria in the lungs. Longer duration of hospitalization in ICU increased the likelihood of hospital- acquired infection. In contrast to the finding of the present study, Kulkarni et al., (2019) demonstrated that hemoglobin value and WBC count have no significant association with the outcome in the term of duration of stay.

Cases with normal radiographs had a milder illness and were admitted to ordinary ward. Regarding chest radiographic abnormalities, varying degrees of lung infiltrations were noted. Consolidation was found mainly in the right lung (16.3\% of all cases). Most cases with lung consolidation required ICU admission. Similar findings were recorded by Al-Naddawi et al., (2009) who observed that the major radiological abnormality was right lower lobe consolidation, while Jayashree et al., (2006) recorded the commonest being bilateral lower lobe infiltrates in children with hydrocarbon poisoning admitted to ICU.

Abd El Salam et al., (2011) confirmed that chest X-ray had a significant correlation with ICU admission and the need for mechanical ventilation. Sen et al. 
(2013) and Kulkarni et al., (2019) demonstrated that chest X-ray features had a significant association with duration of stay.

All non-ICU admitted cases were cured and discharged. Only three cases of ICU admitted cases died representing $1.9 \%$. This was in accordance with the study of Lang et al., (2008) who recorded a mortality rate of $2 \%$, and the Egyptian study of Tawfik and Hafiz (2017) with a percent of mortality of $1.5 \%$ in hydrocarbon poisoned cases. In the majority of cases, the doses of toxic agents ingested in accidental pediatric poisoning are not high enough to lead to fatalities (Malangu et al., 2005). However, a higher fatality rate $(4.2 \%)$ was reported by Jayashree et al., (2006) in a study of children with respiratory distress admitted to ICU.

The present work highlighted that $22.1 \%$ were discharged against medical advice (DAMA) after taking the consent of their legal guardian. Qazi and Saqib, (2018) demonstrated that some of kerosene poisoning cases left the hospital against medical advice as they consumed small quantities and were admitted for observation.

\section{Conclusion}

Accidental ingestion of even small amount of kerosene comprises serious pediatric poisoning. Although most of the children improve without any complications, some may die due to respiratory failure. Although symptomatic pediatric cases with kerosene poisoning usually have a benign clinical course which requires monitoring and supportive care, cases with respiratory distress or altered sensorium are transferred to ICU and mechanical ventilation may be required. Prevention of kerosene poisoning will reduce the number of pediatric admissions caused by poisoning.

\section{Recommendations}

- Increasing public awareness regarding kerosene accessibility at home. Proper kerosene storage using locked containers in a safe place out of reach of children.

- Rapid transfer of poisoned patient to the hospital to prevent complications of kerosene poisoning. They must not be discharged early even if they don't have respiratory symptoms.

- Good parental supervision of their children. Induced vomiting at home in hydrocarbon poisoning should be avoided.

- Kerosene intoxicated patients who are suffering from tachypnea, hypoxemia, and chest retractions should be considered a high-risk group for ICU management to decrease the risk of mortality.

- Patients presenting with moderate or severe grades of PSS should be directly admitted to the ICU for possible need of mechanical ventilation.

\section{References}

Abd El Salam HF, Fayed AM, Abdel Muneum MM (2011): Prediction of the outcome of patients with acute hydrocarbons poisoning using poison severity scoring system; A prospective study. Journal of American Science; 7(4):509-18.
Ahmadu BU, Chafi AN, Difirwiti HC, et al., (2016): An unusual accidental kerosene poisoning. Case Report, ARC Journal of Pediatrics; 2(1): 1-3.

Al-Naddawi M, Al-Chalabi MA, Kamil KM (2009): Kerosene poisoning in children. Iraqi Academic Scientific J.; 8(4):350-5.

Anwar S, Rahman AK, Houqe SA, et al., (2014): Clinical profile of kerosene poisoning in a tertiary level hospital in Bangladesh. Bangladesh J Child Health; 38(1):11-14.

Basu M (2016): Socio-demographic factors, symptoms, complications and treatment of kerosene oil poisoning in children: A hospital based crosssectional study, Sri Lanka Journal of Child Health; 45(2): 72-75.

Biswas G (2012): Kerosene Oil Poisoning. In: Review of Forensic Medicine and Toxicology Including Clinical and Pathological Aspects, $2^{\text {nd }}$ edition, Jaypee Brothers Medical Publishers (P) LTD, New Delhi: 552.

Bond GR, Pieche S, Sonicki Z, et al., (2008): A clinical decision rule for triage of children under 5 years of age with hydrocarbon (kerosene) aspiration in developing countries. Clinical Toxicology; 46 (3):222-229.

Chandrasekhar S, Rahim MA, Quraishi SMS, et al. (2017): An observational clinical study of assessing the utility of PSS (poison severity score) and GCS (Glasgow coma scale) scoring systems in predicting severity and clinical outcomes in OP poisoning. J. Evid. Based Med. Healthc.; 4(38), 2325- 2332.

Das S, Behera SK, Xavier AS, et al., (2020): Prophylactic use of steroids and antibiotics in acute hydrocarbon poisoning in children, Journal of Pharmacy Practice; 33(1) 90-95.

Jayashree M and Singhi S (2011): Changing trends and predictors of outcome in patients with acute poisoning admitted to the intensive care, Journal of Tropical Pediatrics, 57 (5):340-346.

Jayashree M, Singhi S and Gupta A (2006): Predictors of outcome in children with hydrocarbon poisoning receiving intensive care. Indian Pediatr; 43:715-719.

Joshi P and Ross M P (2017): Intensive care of pediatric poisoning cases In: Brent $\mathrm{J}$ et al, 2nd ed. Critical care toxicology. Springer, USA; 205-222.

Kirk MA (2011): Use of the intensive care unit. In: Goldfrank's Manual of Toxicologic Emergencies by Flomenbaum NE, Goldfrank LR, Hoffman RS, Howland MA, Lewin NA, Nelson LS (Eds.), $9^{\text {th }}$ edition, The McGraw-Hill, New York: 148-153.

Kulkarni V, Dhanalakshmi K, Raju K, et al., (2019): Prognostic value of laboratory and radiological parameters in kerosene poisoning, Int $\mathrm{J}$ Contemp Pediatr.; 6(2):811-816.

Kumaravel KS and Rameshbabu B (2016): Kerosene poisoning in childhood: a 3-year retrospective study at a tertiary referral hospital. International 
Journal of Contemporary Medical Research; 3(6):1832-1834.

Lang T, Thuo N and Akech S (2008): Accidental paraffin poisoning in Kenyan children, Tropical Medicine and International Health, 13 (6):845847.

Lifshitz M, Sofer S and Gorodischer R (2003): Hydrocarbon poisoning in children: A 5-year retrospective study. Wilderness Environ. Med. 14: $78-82$.

Madboly AG and Elgendy FS (2014): Epidemiology, clinical characteristics and management of acute hydrocarbons poisoning at Benha Poisoning Control Unit: A One Year Prospective Clinical Study. Ain Shams J. Forensic. Med. Clin. Toxicol.23, 30-42.

Malangu N, Du Plooy WJ and Ogunbanjo GA (2005): Paraffin poisoning in children: What can we do differently?, SA Fam Pract; 47(2): 54-56.

Manzar N, Saad SMA, Manzar B, et al., (2010): The study of etiological and demographic characteristics of acute household accidental poisoning in children - a consecutive case series study from Pakistan. BMC Pediatrics; 10: 2831.

Murmu C M and Das L (2017): Epidemiology of oral poisoning in paediatrics age group, International Journal of Medical Research and Review, 5(7): 769-779.

Nelson LS, Lewin NA, Howland MA et al., (2011): Initial Evaluation of the Patient: Vital Signs and Toxic Syndromes. In: Goldfrank's Manual of Toxicologic Emergencies by Flomenbaum NE, Goldfrank LR, Hoffman RS, Howland MA, Lewin NA, Nelson LS (Eds.), $9^{\text {th }}$ edition, The McGraw-Hill, New York:34.

Persson HE, Sjöberg GK, Haines JA, et al., (1998): Poisoning severity score. Grading of acute poisoning. J Toxicol Clin Toxicol.; 36:205-13.

Prasad R, Karmakar S, Sodhi R, et al., (2011): Bilateral hemorrhagic pleural effusion due to kerosene aspiration. Lung India; 28:130-2.
Qazi M and Saqib N (2018): Clinical profile and outcome of children presenting with poisoning or intoxication: a hospital-based study. Int $\mathbf{J}$ Contemp Pediatr. 5(5):1844-1850.

Sen V, Kelekci S, Sen HS, et al., (2013): An evaluation of cases of pneumonia that occurred secondary to hydrocarbon exposure in children, European Review for Medical and Pharmacological Sciences; 17 (1): 9-12.

Sheikh S, Chang A, Kieszak S, et al., (2013): Characterizing risk factors for pediatric lamp oil product exposures. Clinical Toxicology; 51 (9):871-878.

Shotar AM (2005): Kerosene poisoning in childhood: A 6 year prospective study at Princess Rahmat Teaching Hospital. Neuro Endocrinol Lett; 26:835-8

Siddiqui EU, Razzak JA, Naz F, et al., (2008): Factors associated with hydrocarbon ingestion in children. Journal of the Pakistan Medical Association, 58(11): 608-612.

Singh AK and Gurung PK (2018): Factors contributing to kerosene oil poisoning in children, Journal of BP Koirala Institute of Health Sciences; 1(2):65-68.

Sunilkumar MN and Parvathy VK (2016): Analysis of profile of childhood kerosene poisoning in a tertiary care medical college hospital: Int $\mathbf{J}$ Pediatr Res; 3(4):211-217.

Tawfik HM and Hafiz RN (2017): Predictors of clinical decision rule in hydrocarbon intoxicated cases admitted to Poison Control Center Ain Shams University Hospitals during 2015-2016, Ain Shams Journal of Forensic Medicine and Clinical Toxicology, 28: 149-159.

Venkatesh C, Sriram P, Adhisivam B, et al., (2011): Clinical profile of children with kerosene aspiration, Tropical Doctor, 41:179-180.

\section{تقييم حالات التسمم بالكيروسين :دراسة مستقبلية لمدة ثلاث سنوات بمستثفيات جامعة المنوفية}

$$
\begin{aligned}
& \text { شيرين رجب سليمه' وإيمان رجب' وشيماء عبد العليم' } \\
& \text { الملخص العربي }
\end{aligned}
$$

$$
\begin{aligned}
& \text { المقدمة: يعد الكيروسين سببا شائعا لتسمم الأطفال خاصة في البلدان المنخفضة والمتوسطة الدخل و ترتبط المضاعفات بشكل }
\end{aligned}
$$

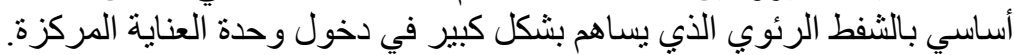

$$
\begin{aligned}
& \text { الغرض من البحث: در اسة هذه المشكلة وتحديد الخصائص التى تساعد في إتخاذ القرار لنقل المرضى للعناية المركزة في حالات } \\
& \text { التسمم الحاد بالكيروسين. }
\end{aligned}
$$

طريقه البحث : شملت الدراسة الأطفال الذين تم إدخالهم الى مركز علاج التسمح بمستشفيات جامعة المنوفية نتيجة التسمح بالكيروسين. تم أخذ التاريخ المرضي و البيانات الطبية. تم عمل فحص طبي شامل وتقسيم الحالات تبعا لدرجة الخطورة.

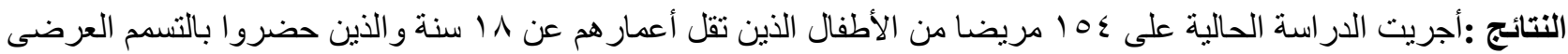

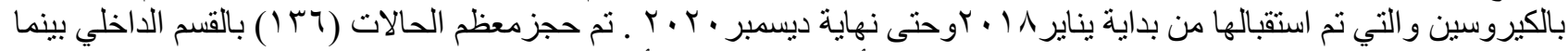

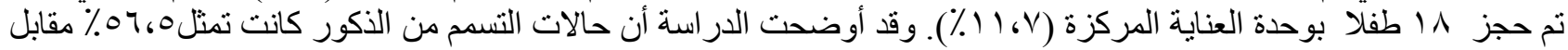




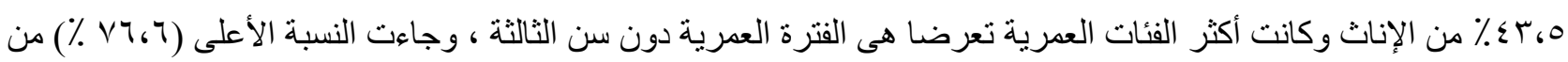

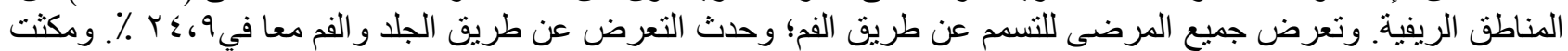

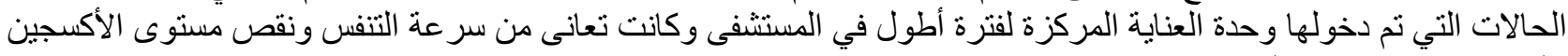

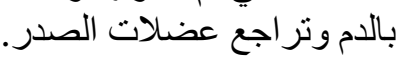

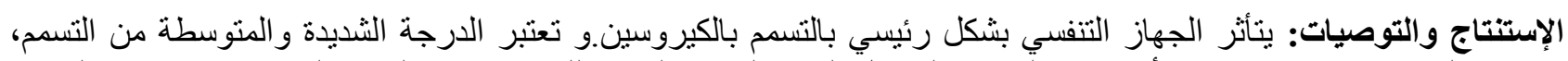

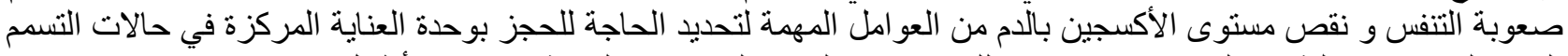
الحاد بالكيروسين. التثقيف المجتمعي ضروري الاكين للحد من هذا التسمم الذي يمكن الوقاية منه عند الأطفال.

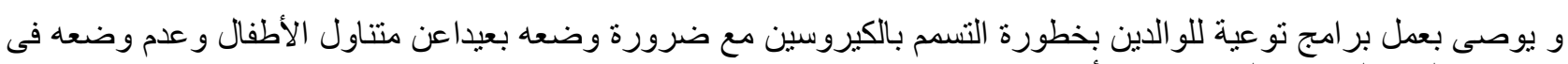

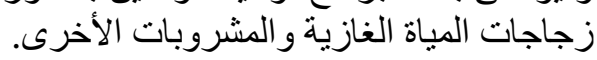

